\title{
Effect of Nitrogen Applications, Micronutrients and Cyanobacteria on Wheat Yield and the Availability of some Nutrients
}

\author{
N. Abd EL-Kader* \\ Soil and Water Dept., Fac. of Agric., Tanta Univ. Tanta, Egypt.
}

\begin{abstract}
W heat (Triticm aestivum L.) plants were cultivated during the season 2013/2014 at the experimental farm of the Faculty of Agriculture, Tanta University, Egypt. The aim was to study the influence of inoculation with a cyanobacterial strain and foliar spray of micronutrient mixed with different humic acid, along with recommended or $1 / 2$ recommended $\mathrm{N}$ doses on availability of nutrients in soil. Available $\mathrm{N}$ and $\mathrm{P}$ in soil, $\mathrm{N}$ and $\mathrm{P}$ content in grain and straw, and wheat yield increased significantly with application of micronutrient mixtures and cyanobacteria inoculation with $1 / 2$ recommended $\mathrm{N}$ doses. Wheat grain and straw yield increased by $25 \%$ and $13 \%$ with application of $1 / 2$ recommended $\mathrm{N}$ dose plus micronutrient mixtures and cyanobacterial inoculation as compared with the recommended $\mathrm{N}$ dose, respectively. The increases in available $\mathrm{N}$ and $\mathrm{P}$ in soil and $\mathrm{N}$ and $\mathrm{P}$ concentrations in grain and straw as well as wheat yield between the plots treated by micronutrient mixtures were non-significant. Results concluded that, the combination between cyanobacterial inoculation and micronutrient mixtures with humic acid reduced the amount of the mineral nitrogen which can lead to saving chemical-N fertilizer (about $50 \%$ ) and improving the soil available $\mathrm{N}$ and $\mathrm{P}$ and grain and straw yield of wheat.
\end{abstract}

Keywords: Cyanobactria, Micronutrients, Nitrogen, Wheat, Fertilization, Inoculation.

\section{Introduction}

Most soils used for crop production in North Nile Delta of Egypt have low fertility accompanied with high $\mathrm{pH}$ and low micronutrients and soil organic matter (SOM) contents (Malakouti, 2008). Under such conditions, crop response to soil application of micronutrients can be very high. Foliar feeding of micronutrients has been more effective and less costly than soil application (El-Fouly and El- Sayed, 1997). Micronutrients are involved in chlorophyll formation, nucleic acid and protein synthesis, and play an active role in several enzymatic activities that control photosynthesis and respiration (Reddy, 2004). Foliar application of micronutrients was reported to have positive effects on 1000-seed weight, plant height, biological yield, grain yield, the harvest index and oil content of sunflower (Babaeian et al., 2011). Potarzycki and Grzebisz (2009) reported that zinc greatly affects nitrogen uptake and metabolism, protein quality, photosynthesis, chlorophyll synthesis, and carbonic anhydrase activity.

Soil-plant-microbe interactions are complex and known to influence the plant growth and productivity (Adesemoye and Kloepper, 2009). With the increasing concern for food and environmental quality and dependence of modern agriculture on the application of chemical inputs, there exists a need to search for viable alternatives for sustainable agriculture (Ashrafuzzaman et al., 2009 and Piromyou et al., 2011). Recently, use of cyanobacterial inoculation has been reported to increase soil fertility through enhanced release of the plant nutrients and is gaining popularity among the farming community due to lower capital cost. Cyanobacteria have been reported to liberate a wide array of extracellular substances, e.g, plant growth regulators, vitamins, amino acids, sugars,

\footnotetext{
*nasserkamal@yahoo.com

DOI: $10.21608 /$ ejss.2018.5616

C2018 National Information and Documentation Centre (NIDOC)
} 
and other metabolites, which have direct or indirect impact on plant growth and yields (Mandal et al., 1999 and Prasanna et al., 2009). Besides their well-established role as nitrogen supplements and tolerance to desiccation, cyanobacteria can be key players in carbon sequestration and improving nutrient use efficiency and crop yields (Rai and Bergman, 2002). The nitrogen fixed by Nostoc sp. in association with what have been taken up by the plant support its growth, improve grain yields and grain quality (Gantar et al., 1995). Ali (2007) indicated that biofertilization applied with mineral fertilizers would have a positive significant effect on plant quality and cost of crop production.

Wheat is the most important cereal crop in Egypt and is the staple food of the people and thus occupies a central position in forming agricultural policies. However, in attempting to develop productive, profitable, and sustainable agriculture systems, several agriculturists turn to farming methods, which are based on biotechnologies (Ghazal, et al., 2011).

Therefore, the aim of this work is to evaluate the influence of Nostoc cyanobacterial inoculation and foliar application of micronutrients sources on soil- available nutrients and wheat yield.

\section{Materials and Methods}

Wheat field experiments were performed during the season 2013/2014 at the experimental farm of the Faculty of Agriculture, Tanta University, El-Gharbia, Egypt, to study the effect of micronutrients spraying and cyanobactria inoculation on wheat (Triticum aestivum cv. Gemiza 9) yield and soil available ( $\mathrm{N}$ and $\mathrm{P}$ ). The physico-chemical analysis according to Page et al. (1982) of the experimental soil is reported in Table 1.

\section{Preparation of mixture micronutrients solutions}

Stock solutions $\left(1 \times 10^{-3} \mathrm{M}\right)$ of $\mathrm{Fe}, \mathrm{Mn}, \mathrm{Zn}$ and $\mathrm{Cu}$ were prepared by dissolving the appropriate weight of pure metal salts (form sulfates) in the least amount of distilled water and then transferred into a 1L measuring flask.. Mixture solutions of metal ions were prepared using different volumes of stock solutions to obtain $2.5 \% \mathrm{Fe}, 1 \% \mathrm{Mn}$, $0.5 \% \mathrm{Zn}$ and $0.1 \% \mathrm{Cu}$. Then, they were mixed with $1.0 \%$ chelating agents for each, EDTA, amino acids and humic acids. Humic acid (extracted from rice straw compost) were taken from Soil Fertility and Plant Nutrition Department, Sakha Agric. Res Station, Egypt.

Egypt. J. Soil. Sci. 58, No. 1 (2018)
The experiment was arranged for randomized complete block design with three replicates.

The treatments were as follows:

T0: Without addition

T1: $168 \mathrm{~kg} \mathrm{~N} \mathrm{ha}^{-1}$ (as recommended $\mathrm{N}$ )

T2: $84 \mathrm{~kg} \mathrm{~N} \mathrm{ha}^{-1}+$ Foliar spray of micronutriments (EDTA)

T3: $84 \mathrm{~kg} \mathrm{~N}$ ha $^{-1}+$ Foliar spray of micronutriments (EDTA) mixture with amino acids

T4: $84 \mathrm{~kg} \mathrm{~N} \mathrm{ha}^{-1}+$ Foliar sprayof micronutriments (EDTA) mixture with humic acid

T5: $84 \mathrm{~kg} \mathrm{~N} \mathrm{ha}^{-1}+$ Foliar spray of micronutriments (EDTA) + cyanobacterial inoculation

T6: $84 \mathrm{~kg} \mathrm{~N} \mathrm{ha-1}+$ Foliar spray of micronutriments(EDTA) mixture with amino acids + cyanobacterial inoculation

T7: $84 \mathrm{~kg} \mathrm{~N} \mathrm{ha}^{-1}+$ Foliar spray of micronutriments (EDTA) mixture with humic acid + cyanobacterial inoculation

The experimental field was prepared and then divided into 24 plots ( $3 \mathrm{~m} \mathrm{X} 3.5 \mathrm{~m}$ each) to represent eight treatments in three replicates. Basal application treatments with $476 \mathrm{~kg} \mathrm{ha}^{-1}$ as superphosphate $\left(15.5 \% \mathrm{P}_{2} \mathrm{O}_{5}\right)$ and $119 \mathrm{~kg} \mathrm{ha}^{-1}$ potassium sulfate $\left(48 \% \mathrm{~K}_{2} \mathrm{O}\right)$ were used for the all plots. Nitrogen as urea $(46 \% \mathrm{~N})$ was applied in three equal doses according to the treatments one dose with grain sowing, second and third doses with the first and the second irrigation. Dried flakes from the soil based cyanobacterial inoculum had inoculated to wheat plants 14 days (as broadcast) after sowing at the rate of one $\mathrm{g}$. $\mathrm{m}^{2}$. Cyanobacterial inoculum was a mixture of Nostoc commune and Nostoc muscorum. The cyanobacteria inoculum was prepared as described by Venkataraman (1972). The Bacterial Laboratory of Soils, Water \& Environ, Res. provided the cyanobacterial inoculum used in this study. Micronutrients were foliar sprayed at the rate of $5.76 \mathrm{~L} \mathrm{ha}^{-1}$ in three doses monthly starting from two weeks after sowing. Wheat plants were harvested on May of 2014. At maturity of plants, one metersquare from each treatment was taken to evaluate the grain and straw. Straw and grain samples of each treatment were oven dried at 70 ${ }^{\circ} \mathrm{C}$ for three days and weighed. Nitrogen and $\mathrm{P}$ in straw and grain were determined according to the methods described by Page et al. (1982).

Available $\mathrm{N}$ was extracted by $2 \mathrm{~N} \mathrm{KCl}$ and determined using a semimicro kjeldahl technique according to Page et al. (1982), and available P was extracted by sodium biocarbonate $0.5 \mathrm{M}$ at $\mathrm{pH} 8.5$ according to Olsen method and measured 
photometrically using ammonium molybedate according to Page et al. (1982)

\section{Statistical analysis}

The results of the season were subjected by analysis in variance and means were compared by the least significant difference (L.S.D) as described by Gomez and Gomez (1984).

\section{Results and Discussion}

Effect of nitrogen, micronutrients and cyanobacterial application on

Soil available $N$ and $P$

Available $\mathrm{N}$ and $\mathrm{P}$ in soil after wheat harvesting increased significantly with the application of mixture micronutrients and cyanobacterial inoculation along with $1 / 2$ recommended $\mathrm{N}$ dose (Table 2). The increases in available $\mathrm{N}$ and $\mathrm{P}$ of soil between the mixtures of micronutrient with chelating agents were non-significant. The available $\mathrm{N}$ and $\mathrm{P}$ concentrations in soil inoculated with cyanobacterial increased above the uninoculation treatment by $6.75 \%$ and by $7.2 \%$ with under applied micronutrients and $1 / 2$ recommended $\mathrm{N}$ dose. Maximum $\mathrm{N}$ and $\mathrm{P}$ concentrations (43.2 and $11.2 \mathrm{mg} \mathrm{kg}^{-1}$ ) were observed in the plot receiving $\mathrm{T} 7$ treatment (Table 2), whereas, the lowest $\mathrm{N}$ and $\mathrm{P}$ concentrations (20.0 and $7.7 \mathrm{mg} \mathrm{kg}^{-1}$ ) were recorded in $\mathrm{T} 0$ treatment.

Sahu et al. (2012) reported that cyanobacterial play an important role to build-up soil fertility. Cyanobacterial are capable of fixing the atmospheric nitrogen. Acea et al. (2003) also showed that soil inoculation with different cyanobacterial strains induced great microbial proliferation as well as high increases in soil organic carbon and available nutrients. Mandal et al. (1999) and Wafaa et al. (2013) reported that inoculation with cyanobacterial might help to improve soil available N, P, and $\mathrm{K}$.

TABLE 1. Some physical and chemical properties of the experimental field

\begin{tabular}{|c|c|c|c|c|c|c|c|c|c|c|}
\hline \multirow{2}{*}{ Seasons } & \multicolumn{3}{|c|}{$\begin{array}{c}\text { Particle size } \\
\text { distribution, } \%\end{array}$} & \multirow{2}{*}{$\begin{array}{l}\text { Texture } \\
\text { Class }\end{array}$} & \multirow{2}{*}{$\begin{array}{c}E C \\
\mathbf{d S m}^{-1}\end{array}$} & \multirow{2}{*}{$\begin{array}{c}\text { pH } \\
(1: 2.5)\end{array}$} & \multirow{2}{*}{$\begin{array}{l}\text { OM } \\
(\%)\end{array}$} & \multicolumn{3}{|c|}{$\begin{array}{l}\text { Available nutrients (mg } \\
\left.\qquad \mathrm{kg}^{-1}\right)\end{array}$} \\
\hline & $\begin{array}{c}\text { Sand } \\
\%\end{array}$ & Silt \% & Clay\% & & & & & $\mathbf{N}$ & $\mathbf{P}$ & $\mathbf{K}$ \\
\hline $2013 / 2014$ & 12.2 & 33.2 & 54.6 & Clay & 3.38 & 7.70 & 1.64 & 19.4 & 6.9 & 264 \\
\hline
\end{tabular}

TABLE 2. Effect of nitrogen, micronutrients and cyanobacterial application on available $N$ and $P$ in soil after wheat harvest

\begin{tabular}{|c|c|c|}
\hline Treatments & Available $\mathrm{N}\left(\mathrm{mg} \cdot \mathrm{kg}^{-1}\right)$ & $\begin{array}{c}\text { Available P } \\
\left(\mathrm{mg} . \mathrm{kg}^{-1}\right)\end{array}$ \\
\hline $\mathrm{T} 0$ & 17.00 & 7.7 \\
\hline $\mathrm{T} 1$ & 23.00 & 7.9 \\
\hline $\mathrm{T} 2$ & 37.33 & 9.17 \\
\hline $\mathrm{T} 3$ & 38.38 & 10.01 \\
\hline $\mathrm{T} 4$ & 40.13 & 10.17 \\
\hline T5 & 39.33 & 10.19 \\
\hline T6 & 41.13 & 10.73 \\
\hline $\mathrm{T} 7$ & 43.23 & 11.20 \\
\hline $\mathrm{LSD}_{0.05}$ & 0.831 & 0.657 \\
\hline
\end{tabular}

T0: Without addition, $\quad \mathrm{T} 1: 168 \mathrm{~kg} \mathrm{~N}$ ha-1 (as recommended $\mathrm{N}$ )

T2: $84 \mathrm{~kg} \mathrm{~N}$ ha-1 + Foliar spray of micronutriments (EDTA)

T3: $84 \mathrm{~kg} \mathrm{~N}$ ha-1 + Foliar spray of micronutriments (EDTA) mixture with amino acids

T4: $84 \mathrm{~kg} \mathrm{~N}$ ha-1 + Foliar sprayof micronutriments (EDTA) mixture with humic acid

T5: $84 \mathrm{~kg} \mathrm{~N}$ ha-1 + Foliar spray of micronutriments (EDTA) + cyanobacterial inoculation

T6: $84 \mathrm{~kg} \mathrm{~N}$ ha-1 + Foliar spray of micronutriments(EDTA) mixture with amino acids + cyanobacterial inoculation

T7: $84 \mathrm{~kg} \mathrm{~N}$ ha-1 + Foliar spray of micronutriments (EDTA) mixture with humic acid + cyanobacterial inoculation 
Cyanobacterial are known to excrete a number of compounds such as polysaccharides, peptides, and lipids during their growth in soil particles, and hold particles together as microaggregates. Brady and Weil (2005) wrote that the decomposition of applied organic materials and bio-fertilizer resulted in reduction in soil $\mathrm{pH}$ through forming various acids, acid - forming, and consequently enhanced the nutrient availability in soil. Nain et al. (2010) found that the formation of hydrocarbonic acids in the rhizosphere of maize root, due to biofertilizer treatment, led to decreasing soil $\mathrm{pH}$, and consequently enhanced the nutrient availability in soil.

$N$ and $P$ concentration (\%) in wheat grains

Data in Table 3 show that $N$ and $P$ concentrations of grain varied from 1.5 and $0.20 \%$ to 1.74 and $0.27 \%$, respectively. $\mathrm{N}$ and $\mathrm{P}$ concentrations in grain and straw increased significantly with the application of micronutrient mixtures and inoculation along with $1 / 2$ recommended $\mathrm{N}$ doses over the uninoculation treatment. Plots treated with cyanobacterial increased $\mathrm{N}$ and $\mathrm{P}$ concentrations in grain compared with recommended $\mathrm{N}$ dose treatment by $5.2 \pm 0.5 \%$ and $18.2 \pm 4.5 \%$ under applied $1 / 2$ recommended $\mathrm{N}$ dose and micronutrient mixtures, respectively. The increases in $\mathrm{N}$ and $\mathrm{P}$ concentrations of grain between the plots treated by micronutrient mixtures were nonsignificant. The observed increases in $\mathrm{N}$ and $\mathrm{P}$ concentrations following Nostoc application mirrored improvements in $\mathrm{N}$ and $\mathrm{P}$ contents of the studied soil. These results are consistent with that obtained by El- Gaml (2006), who indicated that inoculation with cyanobacterial enhanced the
N, P, and K uptake. Results of Abed EL- Rasoul et al. (2004) and Mussa et al. (2003) indicated that spraying nitrogen fixing biofertilizers individually significantly increased $\mathrm{N}, \mathrm{P}$, and $\mathrm{K}$ concentration by grains and straw over the control treatments (without spraying biofertilizers) confirmed increasing the nutrient concentration by wheat grain and straw in response to the use of cyanobacterial as an activator biofertilizer separately. This trend is parallel to what was shown by El- Mancy et al. (1997) who found that the combination between biofertilizers with reduced amount of the mineral nitrogen can lead to saving chemical-N fertilizer (about $50 \%$ ) and improving the NPK uptake by rice grains and straw. The grain and straw yields, and NPK uptake of wheat plants increased by Azospirillum inoculation with $1 / 2$ recommended $\mathrm{N}$ doses as compared to the control without inoculation (ElKasas, 2002).

\section{Grain yield of wheat}

Data in Table 4 show that grain and straw yield of wheat significantly increased with the application of $1 / 2$ recommended $\mathrm{N}$ doses along micronutrients and cyanobacterial inoculation. Wheat grain and straw yield increased by $25.3 \%$ and $12.8 \%$ with $1 / 2$ recommended $\mathrm{N}$ dose under the application of micronutrient mixtures and cyanobacterial inoculation as compared with the recommended $\mathrm{N}$ dose, respectively. Inoculation with Nostoc along with $1 / 2$ recommended $\mathrm{N}$ dose and micronutrient mixtures increased grain and straw yield by $14.5 \%$ and $9.04 \%$, compared to the uninoculated treatment for the same treatments. Paudel et al. (2012) found that the cyanobacteria

TABLE 3. Effect of nitrogen, micronutrients and cyanobacterial application on $N$ and $P$ concentration in wheat grain and straw yield

\begin{tabular}{|c|c|c|c|c|}
\hline \multirow[t]{2}{*}{ Treatments } & \multicolumn{2}{|c|}{$\begin{array}{c}\text { N concentration } \\
(\%)\end{array}$} & \multicolumn{2}{|c|}{$\begin{array}{r}\text { P concentraion } \\
(\%)\end{array}$} \\
\hline & grain & straw & grain & straw \\
\hline T0 & 1.5 & 0.38 & 0.20 & 0.021 \\
\hline $\mathrm{T} 1$ & 1.65 & 0.40 & 0.22 & 0.022 \\
\hline $\mathrm{T} 2$ & 1.67 & 0.41 & 0.23 & 0.048 \\
\hline $\mathrm{T} 3$ & 1.69 & 0.47 & 0.25 & 0.049 \\
\hline $\mathrm{T} 4$ & 1.70 & 0.43 & 0.26 & 0.059 \\
\hline $\mathrm{T} 5$ & 1.69 & 0.45 & 0.25 & 0.059 \\
\hline T6 & 1.70 & 0.47 & 0.26 & 0.068 \\
\hline $\mathrm{T} 7$ & 1.74 & 0.49 & 0.27 & 0.077 \\
\hline $\operatorname{LSD}_{0.05}$ & 0.055 & & 0.015 & 0.018 \\
\hline
\end{tabular}

Egypt. J. Soil. Sci. 58, No. 1 (2018) 
TABLE 4. Effect of nitrogen, micronutrients and cyanobacterial application on wheat grain and straw yield.

\begin{tabular}{|c|c|c|}
\hline Treatments & $\begin{array}{c}\text { Grain yield } \\
\left(\mathbf{t} . \mathbf{~ h a}^{-1}\right)\end{array}$ & $\begin{array}{c}\text { Straw yield } \\
\left(\mathbf{t} \mathbf{~ h a}^{-1} \mathbf{)}\right.\end{array}$ \\
\hline $\mathrm{T} 0$ & 3.01 & 5.29 \\
\hline $\mathrm{T} 1$ & 5.11 & 8.15 \\
\hline $\mathrm{T} 2$ & 5.51 & 8.30 \\
\hline $\mathrm{T} 3$ & 5.57 & 8.45 \\
\hline $\mathrm{T} 4$ & 5.70 & 8.55 \\
\hline $\mathrm{T} 5$ & 6.32 & 9.09 \\
\hline $\mathrm{T} 6$ & 6.40 & 9.10 \\
\hline $\mathrm{T} 7$ & 6.49 & 9.40 \\
\hline $\mathrm{LSD}$ & 0.072 & 0.166 \\
\hline
\end{tabular}

inoculated gave a significant increase in all parameters of rice yield over an uninoculated treatment. The increases in grain and straw yield between the treatments of micronutrient mixtures were non-significant. Grain and straw yield of wheat significantly increased with the application of micronutrient mixtures with $1 / 2$ recommended $\mathrm{N}$ doses as compared with recommended $\mathrm{N}$ dose treatment. Similar results for 25 field experiments showed that $\mathrm{Fe}, \mathrm{Mn}, \mathrm{Zn}$, and $\mathrm{Cu}$ fertilization significantly increased grain yield with the application of these nutrients (Ziaeian and Malakouti, 2001). The increase of grain and straw weight of wheat due to micronutrients foliar application might be due to their positive effects on assimilates translocation, activation of photosynthetic enzymes, chlorophyll formation and improvement of plant growth (Yassen et al., 2010). Micronutrients increase the photosynthesis rate and improve leaf area, thus seed yield will be increased (Cakmak et al. 1999). Micronutrient elements play a critical role in plants that lead to increasing leaf area index and thereby increase light absorption and increase the amount of dry matter accumulation and economic yield (Ravi et al., 2008). Foliar application of micronutrients particularly $\mathrm{Zn}$ and $\mathrm{Mn}$ in small amounts had a significant positive effect on grain yield and oil content of sunflower (Babaeian et al., 2011) and yield of bean (Seifi Nadergholi et al., 2011).

\section{Conclusion}

The results of this study revealed that the available $\mathrm{N}$ and $\mathrm{P}$ in soil, $\mathrm{N}$ and $\mathrm{P}$ concentrations in grain and straw as well as wheat yield grain and straw yield of wheat significantly increased in the plots treated with $1 / 2$ recommended $\mathrm{N}$ doses with micronutrient mixtures and cyanobacterial inoculation. The study for the first time illustrated the combination between biofertilizers and micronutrient mixtures with humic acid with a reduced amount of the mineral nitrogen can used, leading to saving about $50 \%$ of chemical-N fertilizer (and improving the soil available $\mathrm{N}$ and $\mathrm{P}$ and grain and straw yield of wheat.

\section{$\underline{\text { References }}$}

Abd EL- Rasoul, Sh. M., Hanna, Mona M. , Aref, Elham M. and Ghazal, F. M. (2004) Cyanobacterial and effective emicroorganisms (EM) as possible biofertilizers in wheat production. J. Agric. Sci. Mansoura Univ., 29 (5), 2783 - 2793.

Aceam M.J., Prieto-Fernández, A. and Diz-Cid, N. (2003) Cyanobacteriall inoculation of heated soils: effect on microorganisms of $\mathrm{C}$ and $\mathrm{N}$ cycles and on chemical composition in soil surface. Soil Biol. Biochem. 35, 513-524

Adesemoye, A.O., and Kloepper, J.W. (2009) Plantmicrobes interactions in enhanced fertilizer use efficiency. Appl. Microbiol. Biotechnol. 85, 1-12

Ali, M. M. E. (2007) Growth of wheat plant on a light texture soil as influenced by water stress and some soil conditioners. M.Sc. Thesis, Fac. Agric., Banha Univ.

Ashrafuzzaman, M., Hossen,F.A., Razi, I. M., Hoque,M. A., Islam, M. Z., Shahidullah, S. M. and Meon. S. (2009) Efficiency of plant growthpromoting rhizobacteria (PGPR) for the enhancement of rice growth. Afr. J. Biotech. 8 (7),1247-1252

Babaeian, M., Piri,I., Tavassoli, A., Esmaeilian Y. and Gholami, H. (2011) Effect of water stress and micronutrients $(\mathrm{Fe}, \mathrm{Zn}$ and $\mathrm{Mn}$ ) on chlorophyll fluorescence, leaf chlorophyll content and 
sunflower nutrient uptake in Sistan region. Afr. J. Agric. Res. 6 (15), 3526-3531.

Brady, N. C. and Weil, R. R., (2005) "The Nature and Properties of Soils". 13 th ed. p. 976. Pearson education, Singapure.

Cakmak, I., Kalayci, M., Ekis, H., Brauni, J., Kilinc, Y. and Yilmaz, A. (1999) Zn deficiency as a practical problem in Plant and human nutrition in Turkey: a NATO science for stability project. Field Crop Res. 60, 175- 188

Eletr ,Wafaa M. T., Ghazal, F. M., Mahmoud, A. A. and Yossef, Gehan H. (2013) Responses of Wheat - Rice Cropping System to Cyanobacterial Inoculation and Different Soil Conditioners Sources under Saline Soil. Nat Sci. 11(10),118-129].

El-Fouly, M.M. and El-Sayed, A.A. (1997) Foliar fertilization: An environmentally friendly application of fertilizers. Dahlia Greidinger International Symposium on Fertilization and Environment, 24-27 March, Haifa, Israel, John, I.(ed.):346-357

El-Gaml,Naayem, M.M. (2006) Studies on cyanobacterial and their effect on some soil properties. M.Sc. Thesis. Soil Dept. Faculty of Agriculture , Banha, Univ. Kalubia Governorate, Egypt.

EL-Mancy, M. H., Kotb, M. Th. A., El-Hamdi, Kh. H. and Hammad, S. A. (1997) N, P and K contents of rice crop in relation to algalization combined with N, P fertilization. J. Agric. Sci., Mansoura Univ. 22, (9), 3053-3065.

Gantar, M., Rowell, P. and Kerby, N. W. (1995) Role of extracellular polysaccharides in the colonization of wheat (Triticum vulgarie L.) roots by $\mathrm{N}_{2}$-fixing cyanobacterial. Biol. Fertl. Soils. 19, 41-48.

Ghazal, F. M., EL-Sayeda, A. H. and Nasef, M. A. (2011) Response of wheat plants to em (effective microorganisms) application and/or cyanobacterial inoculation under sandy soil condition. J. Agric. Chem. and Biotechn. Mansoura Univ., 2 (2), 61-76.

Gomez, K. A. and Gomez, A. A. (1984) "Statistical Procedures for Agricultural Research". Wiley, New York, NY, USA.

Malakouti, M. .J. (2008) The Effect of micronutrients in ensuring efficient use of macronutrients. Turk. $J$. For. 32, 215-220.

Malakouti, M. J. and Tehrani, M. H. (1999) Effect of micronutrients in yield increase and improvement of crops quality. Tarbiat Modarres University Press.

Mandal, B. K., Velk, P. L. G. and Mandal, L. N. (1999) Beneficial effects of blue-green algae and Azolla, excluding supplying nitrogen, on wetland rice fields: a review. Biol. Fertl. Soils, 28, 329-342.

Movahhedy-Dehnavy M., Modarres-Sanavy S. A. M. and Mokhtassi-Bidgoli A. (2009) Foliar application of zinc and manganese improves seed yield and quality of safflower (Carthamus tinctorius L.) grown under water deficit stress. Indian Crops Prod. 30 (1), 82-92.

Mussa, S. A. I. B., Hanna M. M. and Ghazal F. M. (2003) Effect of Cyanobacterial- wheat association on wheat growth and yield components. Egypt. J. Biotechnol. 14, 164-174.

Nain, L., Rana,A., Joshi,M., Shrikrishna,J. D., Kumar, D., Shivay,Y. S., Paul S. and Prasanna, R.., 2010. Evaluation of synergistic effects of bacterial and cyanobacteriall strains as biofertilizers for wheat. Plant Soil, 331, 17-230

Page, A. L., Miller, R. H. and Keeney, D. R. (1982) "Methods of Soil Analysis 11- Chemical and Microbiological Properties". Soil Sci. Amer. Madison, Wisconsin, U.S.A.

Paudel, Y. P., Pradhan,S., Pant, B. and Prasad, B. N. (2012) Role of blue green algae in rice productivity. Agric. Biol. J. N. Am., 3, 332-335.

Piromyou P., Buranabanyat,B., Tantasawat,P., Tittabutr,P., Boonkerd N. and Teaumroong, N. (2011) Effect of plant growth promoting rhizobacteria (PGPR) inoculation on microbial community structure in rhizosphere of forage corn cultivated in Thailand. Eur. J. Soil Biol. 47, 44-54

Potarzycki J. and Grzebisz, W. (2009) Effect of zinc foliar application on grain yield of maize and its yielding components. Plant Soil Environ. 55(12), 519-527.

Prasanna, R., Jaiswal,P., Nayak,S., Sood A. and Kaushik, B. D. (2009) Cyanobacteriall diversity in the rhizosphere of rice and its ecological significance. Indian J. Microbiol. 49, 89-97

Rai, A. N. and Bergman, B. (2002) Creation of new nitrogen-fixing cyanobacterial associations. Proc. Royal Irish Acad. 102B:65-68

Ravi, S., Channal,H. T., Hebsur, N. S., Patil B. N. and Dharmatti, P. R. (2008) Effect of sulphur, zinc and iron nutrition on growth, yield, nutrient uptake and quality of safflower (Carthamus tinctorius L.). Karnataka J. Agric. Sci. 21(3), 382-385.

Egypt. J. Soil. Sci. 58, No. 1 (2018) 
Reddy, S.R. (2004) "Principles of Crop Production Growth Regulators and Growth Analysis", $2^{\text {nd }}$ ed. Kalyani Publishers, Ludhiana, India.

Sahu, D., Priyadarshani, I. and Rath, B. (2012) Cyanobacterial - as potential biofertilizer. An Online International J. 1, 20-26.

Sarkar, D., Mandal B. and Kundu, M. C. (2007) Increasing use efficiency of boron fertilisers by rescheduling the time andmethods of application for crops in India. Plant Soil. 301, 77-85.

Seifi Nadergholi, M., Yarnia, M. and Rahimzade Khoei, F. (2011) Effect of zinc and manganese and their application method on yield and yield components of common bean (Phaseolus vulgaris L. CV. Khomein). Middle- East J. Sci. Res. 8 (5), 859-865.
Yassen, A. 1., Abou El-Nour, E. A. A. and Shedeed S. (2010) Response of Wheat to Foliar Spray with Urea and Micronutrients. Journal of American Science, 6 (9) pp.14-22.

Ziaeian, A. H. and Malakouti, M. J. (2001) Effects of $\mathrm{Fe}, \mathrm{Mn}, \mathrm{Zn}$ and $\mathrm{Cu}$ fertilization on the yield and grain quality of wheat in the calcareous soils of Iran. Food Security and Sustainability of AgroEcosystems, pp.840-841.

(Received: 23/3/2016; accepted: $25 / 5 / 2016$ )

Venkataraman, G. S. (1972) Biofertilizer and rice cultivation. Today and Tomorrow. New Delhi, India. 81- 84.

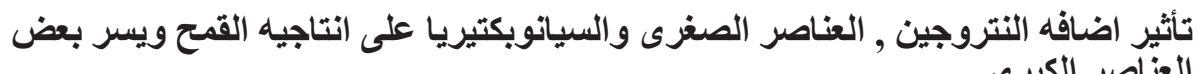

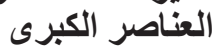
قنس الار اضبى القادر والمياه ـ كليه الزر اعه ـ جامعه طنطا ـ طنطا ـ مصر.

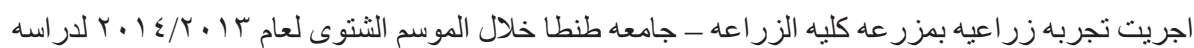

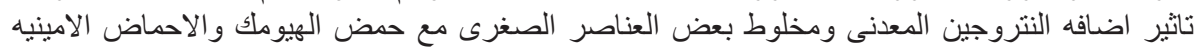

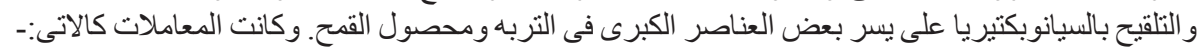

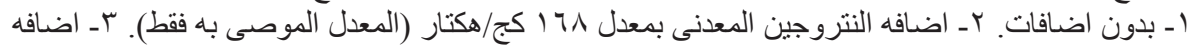

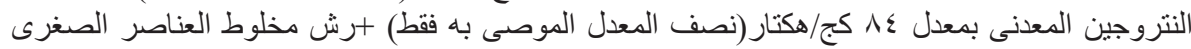

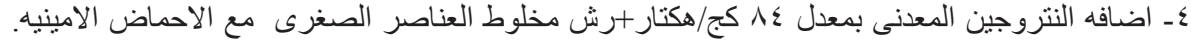

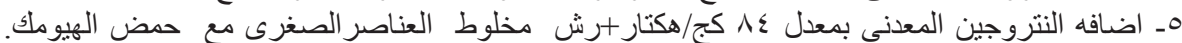

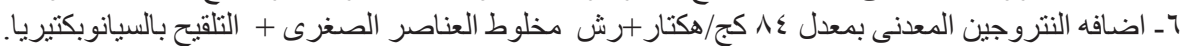

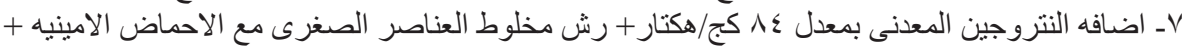

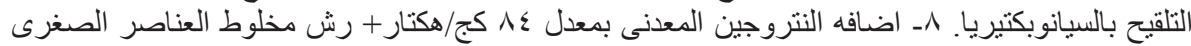

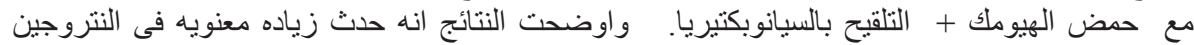

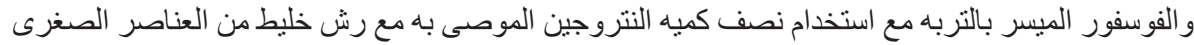

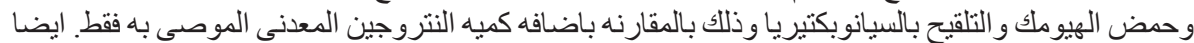

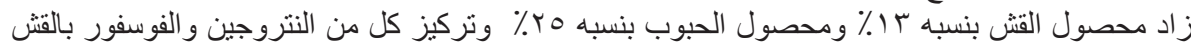

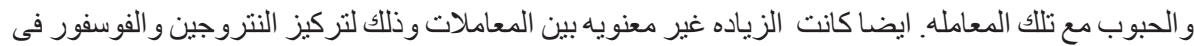

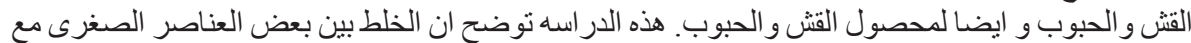

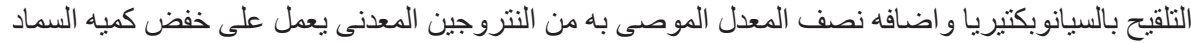

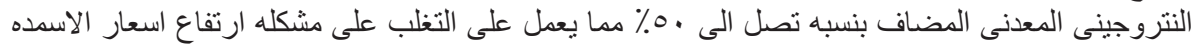

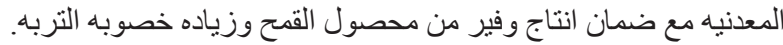

